\title{
Optical and Ultrastructural Study of the Pollen Grain Development in Hermaphrodite Papaya Tree (Carica papaya L.)
}

\author{
Lídia Márcia Silva Santos ${ }^{1}$, Telma Nair Santana Pereira ${ }^{1 *}$, Margarete Magalhães de \\ Souza $^{2}$, Pedro Correa Damasceno Junior ${ }^{1}$, Fabiane Rabelo da Costa ${ }^{1}$, Beatriz Ferreira \\ Ribeiro $^{1}$, Noil Gomes de Freitas $^{1}$ and Messias Gonzaga Pereira ${ }^{1}$ \\ ${ }^{1}$ Universidade Estadual do Norte Fluminense Darcy Ribeiro (UENF); Centro de Ciências e Tecnologias \\ Agropecuárias; Laboratório de Melhoramento Genético Vegetal; Av. Alberto Lamego, 2000; Parque Califórnia; \\ telmasp@uenf.br; 28013-60; Campos dos Goytacazes - RJ - Brazil. ${ }^{2}$ Departamento de Ciências Biológicas; \\ Universidade Estadual Santa Cruz(UESC); Km 16 Rodovia Ilhéus-Itabuna; 45.650-000; Ilhéus - BA - Brazil
}

\begin{abstract}
The objective of this study was to describe the pollen grain development in hermaphrodite papaya tree. The flower buds were collected at different stages of the development and the anthers were treated chemically for observation under optical and electronic transmission microscopes. The pollen grain development followed the normal pattern described for the Angiosperms. The pollen grain development was described from meiocyte to the mature pollen grain. In the microsporogenesis, the microspore mother cells or the meiocytes underwent meiosis giving rise to the tetrads that were enclosed by the calose. Later, the tetrads were released by the dissolution of the calose by calase activity and microspores underwent mitosis. Microgametogenesis was characterized by asymmetrical mitotic division of each microspore giving rise to bi-nucleate pollen grains. The structures similar to the plastids were found in the cytoplasm and close to the nucleus of the generative cell. Gradual degeneration was observed in the tapetum during the male gamete development.
\end{abstract}

Key words: Carica papaya, microsporogenesis, microgametogenesis, pollen grain, ultrastructure

\section{INTRODUCTION}

The papaya tree is a polygamous species presenting individuals with male, female and hermaphrodite flowers. The male flower is grouped in panicle-type inflorescences, with a long, straight corolla tube and five free petals. It has ten functional stamens, five upper and five lower, fused to the petals. It may present a very rudimentary and generally sterile female organ (Ronse Decraene and Smets, 1999). The female flower is observed in a cluster of two or three flowers on the leaf axis. Their petals are free to the lower part of the corolla; the ovary is large and rounded with the stigma in the upper portion, which is divided into five papillae. It does not present stamens but, if present, they are rudimentary. The elongated hermaphrodite flower presents short peduncles in small groups, originating on the leaf axis. They are small flowers and the petals are fused to the base or to almost half their length. The male organ presents ten functional stamens, placed in two series of five,

*Author for correspondence 
and yellow colored anthers. The female organ consists of an elongated ovary and papillae stigma. Several floral alterations, such as five-stamened pentandria, carpelloidy and female sterility are observed in hermaphrodite papaya trees, probably due to the environmental influence during flower development (Storey, 1958).

Several studies have been carried out on the papaya tree, but there are few on male and female gamete development. This type of study can generate data of practical use on the formation of the pollen grains and their relationship with the reproduction mechanism of the crop. Considering the lack of data on the reproductive biology of the papaya, it is necessary to establish the pattern of gamete development as well as to generate knowledge that helps to clarify other aspects of the reproductive biology of the crop. The objective of this work was to study the anatomic modifications that occurred during the pollen grain development in the hermaphrodite flowers of the papaya.

\section{MATERIALS AND METHODS}

The flower buds at different stages of the development were collected at random from the hermaphrodite plants of the Solo variety. The anthers were fixed in $2.5 \%$ glutaraldehyde and $4 \%$ paraformaldehyde in $0.1 \mathrm{M}$ sodium cacodylate buffer solution, $\mathrm{pH} 7.2$, for two hours at the room temperature. After fixing, the flower buds were washed three times in $0.1 \mathrm{M}$ cacodylate buffer for 30 minutes each time, and post fixed with $1 \%$ osmium tetroxide in $0.1 \mathrm{M}$ sodium cacodylate buffer for one hour. The anthers were dehydrated in ethanol series 50, 70, 90, and 100\% (twice) for a period of one hour at each step. They were blocked in Spurr resin at an ethanol/resin proportion of 3:1, 2:1, 1:1, 1:2, 1:3, and pure Spurr resin (Spurr, 1969); at each step the material remained in the solution for eight hours at room temperature. After infiltration, the anthers were included in the special silicon molds, covered by the Petri dishes and submitted to $70^{\circ} \mathrm{C}$ for $12 \mathrm{~h}$.

For the observation under optical microscope (OLYMPUS BX60), the anthers included in the resin were cut in semi fine sections $(0.3-0.5 \mu \mathrm{m})$ with an ultra microtome (LEICA RM2145). The cuts were collected on the slides and stained with the methylene azur II blue for five minutes on a heated plate and counterstained in $2.5 \%$ basic fuchsine solution for 30 seconds at room temperature (Humphrey and Pittman, 1974). After staining, the cuts were set with the entelan and cover sliped.

For observation under the transmission electronic microscope (ZEISS 900, A 60KV), ultra fine cuts were made ( 50 to $60 \mathrm{~nm}$ ) with a diamond knife of the same blocks used for the optical microscope observations. The cuts were collected on the copper grids of 200 mesh, stained with the uranyl acetate for 20 minutes, washed in the distilled water, and then contrasted with the lead citrate for five minutes (Venable and Coggeshall, 1965), washed once again in the distilled water and dried on the filter paper.

\section{RESULTS AND DISCUSSION}

The pollen grain development followed the normal pattern of the development described for most of the Angiosperms (Maheswahri, 1950). The young anther presented two different groups of the cells, the reproductive and the nonreproductive; the reproductive cells gave rise to the pollen grains and the nonreproductive cells gave rise to tapetum cells that surrounded the reproductive cells. Rounded meiocytes or microspore mother cells (MMC) were observed close to one another, surrounded by the tapetum cells (Fig. 1, a). These MMC underwent the meiosis and after the first meiotic division, telophase $I$, resulted in the meiocytes with two haploid nuclei, future dyads with their chromosomes at the poles (Fig. 1, b). The meiosis was not synchronized in the locule, that means that different phases of the meiosis were observed; but all were in the meiosis I. At the end of meiosis, each MMC, after cytokinesis, gave rise to a group of four haploid nuclei, the tetrads, which remained enclosed in the calose (Fig. 1, c). Cytokinesis was of the simultaneous type found in at least 186 Angiosperm families. In this type of cytokinesis, there is no wall formation after meiosis I and the members of the tetrad become isolated from each other by a calose wall which is continuous around the tetrad (Esau, 1974; Souza and Pereira, 2000). The tetrad organization pattern was of the tetrahedral type (Esau, 1974). Later, the calose was dissolved by the calase action, releasing the young microspores in the anther locule (Fig. 1, d). They presented several small vacuoles, structures similar to the plastids and a prominent nucleus, placed in the center of the cell. The microspores at a more advanced stage 
presented large but fewer vacuoles (Fig. 1, e), probably resulting from the fusion of the several small vacuoles as described by Horner and Palmer (1995). Each microspore nucleus underwent asymmetrical mitosis, giving rise to bi-cellular pollen grains with the vegetative and generative cell (Fig. 1, f), although Frankel and Galun (1977) reported tri-cellular pollen grains for the Caricaceae family. Bi-cellular pollen grains are found in at least 192 and tri-cellular pollen grains in at least 150 Angiosperm families (Esau, 1974). In the bi-cellular pollen grain, the generative cell undergoes two mitotic divisions during the pollen grain germination and the pollen tube growth occurs, thus generating the two-gamete nuclei that participate in the double fertilization. The papaya mature pollen grain presented a rounded shape with three germination pores or the apertures (Fig. $1, \mathrm{f})$.

During the pollen grain development, the tapetum cells showed signs of the degeneration, with altered cytoplasmic contents and cell morphology. These cells seemed to exude some material similar to polenkitt. Gabarayeva (1995) stated that polenkitt conferred variety to the pattern of exine projections, spines and grooves and functioned as a barrier, preventing pathogen entry in the pollen grain, and also was resistant to biodegradation. Ultrastructurally, the MMC presented a dense cytoplasm containing many small vessels, a conspicuous centralized nucleus, with dispersed chromatin and a well-developed nucleolus (Fig. 2, a). The MMCs were isolated from the others by a layer of relatively thin calose, secreted by the tapetum cells. At a more advanced stage, the layer of calose became thicker; the cytoplasm remained dense with a centralized nucleus and an even more developed nucleolus (Fig. 2, b). McCormick (1993) suggested that there was communication between the meiocytes through the plasmodesmas, establishing synchrony in the first meiotic division. In this study, some cells were very close to one another, but no cytoplasmic bridges were observed. The tapetum cells around the meiocyte were, at times, binucleate with a vacuolated cytoplasm, a large quantity of dictiosomes and endoplasmatic reticulum (Fig. 2, c). Frankel and Galun (1977) stated that there was interdependency among the meiocytes and they depended on the cytoplasmic connections with the tapetum cells. These connections decreased as the calose thickened and non-synchronization of the stages of the second meiocyte division could arise, suggesting that the nucleous was independent of the meiocyte. The tapetum and the other anther cell layers were preserved until the intermediate microspore stage as was reported in soybean by Horner and Palmer, (1995). At this stage, the tapetum cell layers that were still quite thick, presented large vacuoles in their cytoplasm; these cells were mononucleate or binucleate, with one or two nucleoli. These cytoplasmatic characteristics were probably related with the stocking necessary substances and essential proteins synthesis that were possibly used for the nutrition and perfect development of the future pollen grains (Polowick and Sawhney, 1993).

The tetrad presented a thick calose sheath (Fig. 2, d) that increased the distance between the cells; at this time, microspore wall formation was initiated. Gabarayeva (1995) studying Anaxagorea brevipes (Annonaceae) stated that the calose sheath was not an obstacle that prevented the transport of the substances originating from other anther tissues, mainly from the tapetum cells, to the meiocytes. The microspore, when released from calose, had a large nucleus, which migrated from the center to the microspore wall (Fig. 3, a). The microspores had the exine wall with their layers already formed and the tapetum cells showed signs of the degeneration without the wall delimitation. Externally, the microspores had thick diameters with a larger exine wall and the intine reached its maximum size. The opening of the microspores was observed close to the exine layer and evident intine layer (Fig. 3, b). Noher de Halac et al. (2003) reported that intine consisted of a rigid skeleton structure of the cellulose microfibriles and a matrix similar to the pectin gel, a different type of the polysaccharide and glycoprotein.

According to the authors, the intine was related to a specialized functions of the germination pore and with the growth of the pollen tube. After mitosis of the microspore, the pollen grain showed two nuclei/cells, the vegetative and the generative (Fig. 3 , c). The vegetative cell cytoplasm contained many very small vacuoles that decreased in the size after the first mitotic division. 


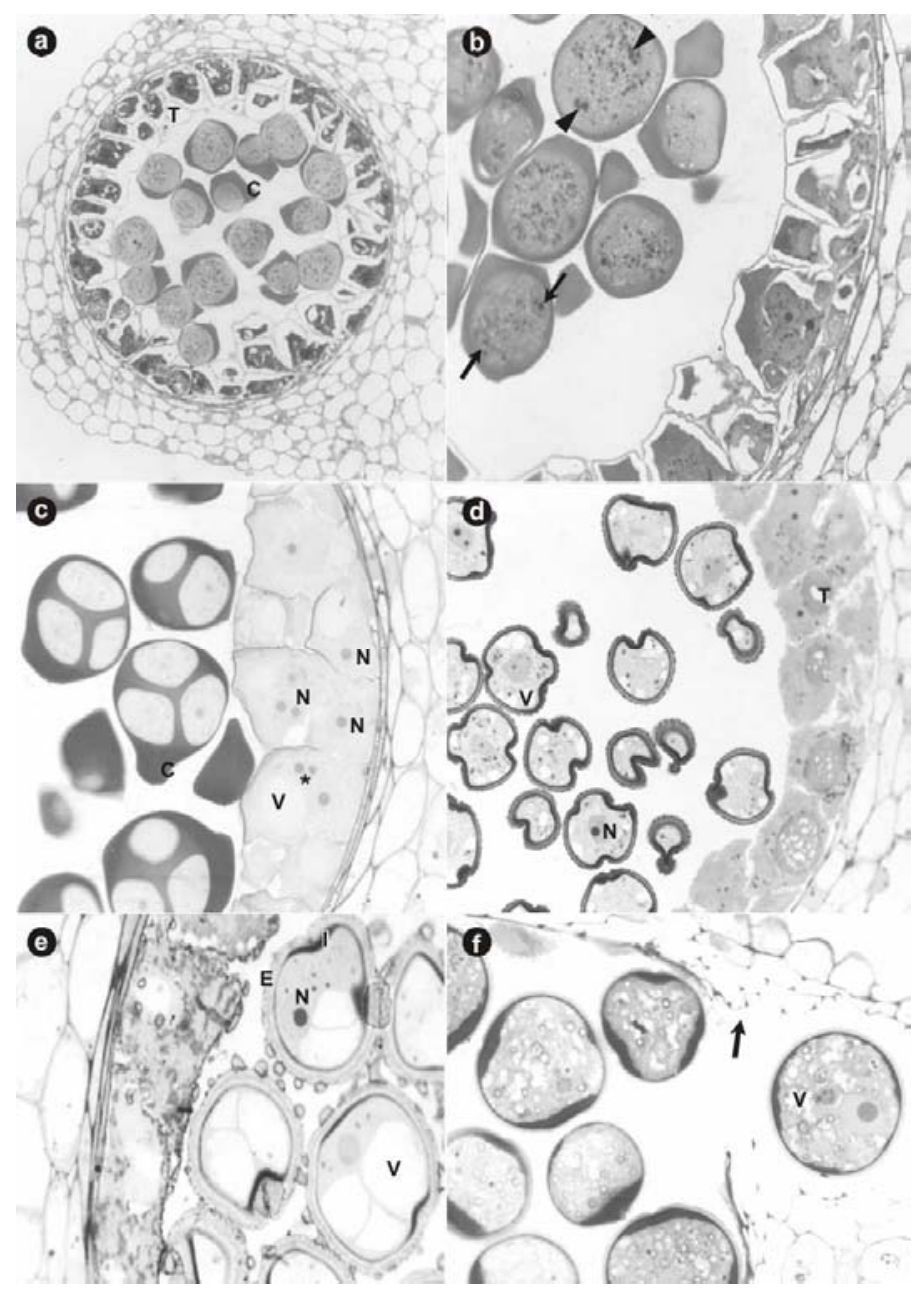

Figure 1 - Pollen grain development in papaya. a) Locule showing the meiocytes close to each other and isolated by calose (x 1800). b) Meiocyte at anaphase I showing the chromosomes in the cell pole (arrow), future dyads (x 3500). c) Detail of locule showing the tetrad enclosed by calose and binucleated tapetum cells (*) (x 2500). d) Young microspores after released from calose (x 4500).e) Detail of the young microspore showing the vacuole, pollen grain wall and the nucleus (x 3000). f) Bicellulated pollen grain, showing the vegetative and generative cells (x 3000). C: callose; T: tapetum; N: nucleus; V: vacuole; E: exine 


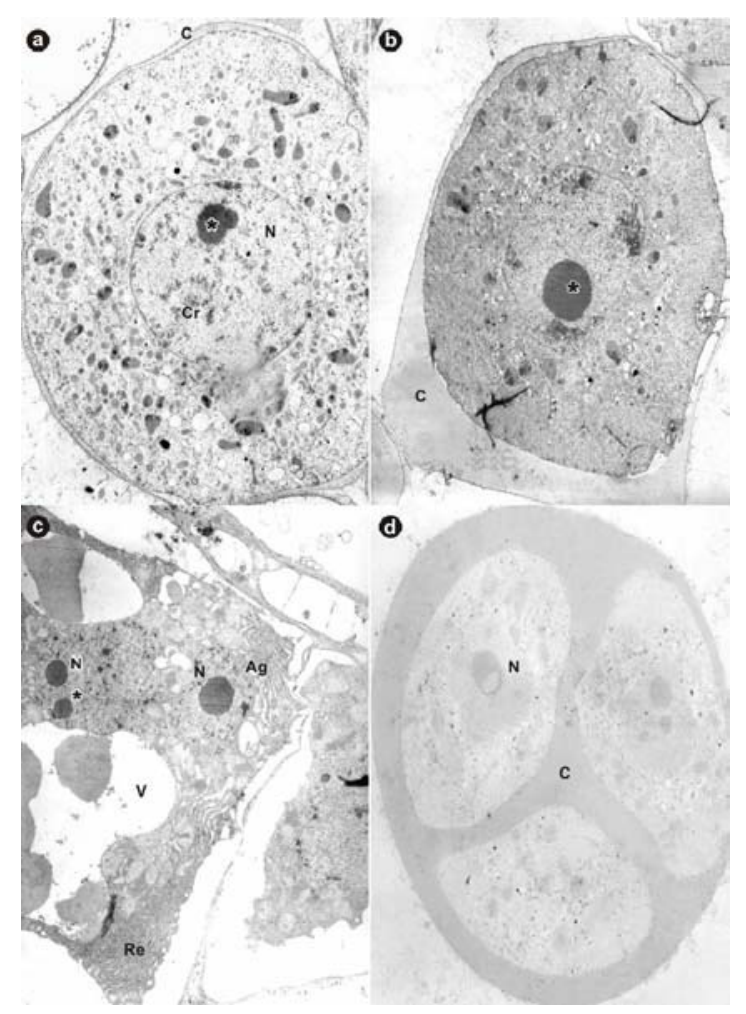

Figure 2 - Transmission electron microscope photographs of pollen grain development in papaya. a) Meiocyte showing the central nucleus, nucleolus (*), and dispersed chromatin, all enclosed into the callose (x 3.000). b) Meiocyte in advanced development stage showing a prominent nucleolus $(*)$ and thicker callose (x 4500). c) Tapetum cell showing the nucleus and nucleolus $(*)(\mathrm{x} 4500)$. d) Detail of tetrad showing the three nuclei and callose around them (x 4500). C: calose; Cr: cromatina; N: nucleus; $V$ : vacuole; Ag: apparatus Golgi; Re: endoplasmatic reticulum;

In addition to the vacuoles, structures similar to the plastids, probably amyloplasts and leucoplasts, and lipid droplets were found widely distributed throughout the cytoplasm (Fig. 3, d-f). The vegetative cell had a smaller nucleus than the generative cell, with diffused genetic material. A developed endoplasmatic reticulum was observed close to its nucleus, and next to this, bodies similar to the lipids (Fig. 3, e). Polowick and Sawhney (1993) and Rodríguez-Garcia et al. (2003) believed that the appearance of lipid bodies in the pollen grain could be related to the energy production for the pollen grain germination or for the pollen tube wall synthesis.

The generative cell presented very little cytoplasm, a relatively large nucleus with a large nucleolus. In the present study, structures similar to the plastids were observed very close to the nucleus of the generative cell (Fig. 3, f). The nature of papaya pollen grain was lipidic as observed by
Damasceno Júnior (2004). This was correlated with the anemophily pollination, validating the observations made by Storey (1969) that the wind was the main means of the pollen dispersal of the papaya crop. 


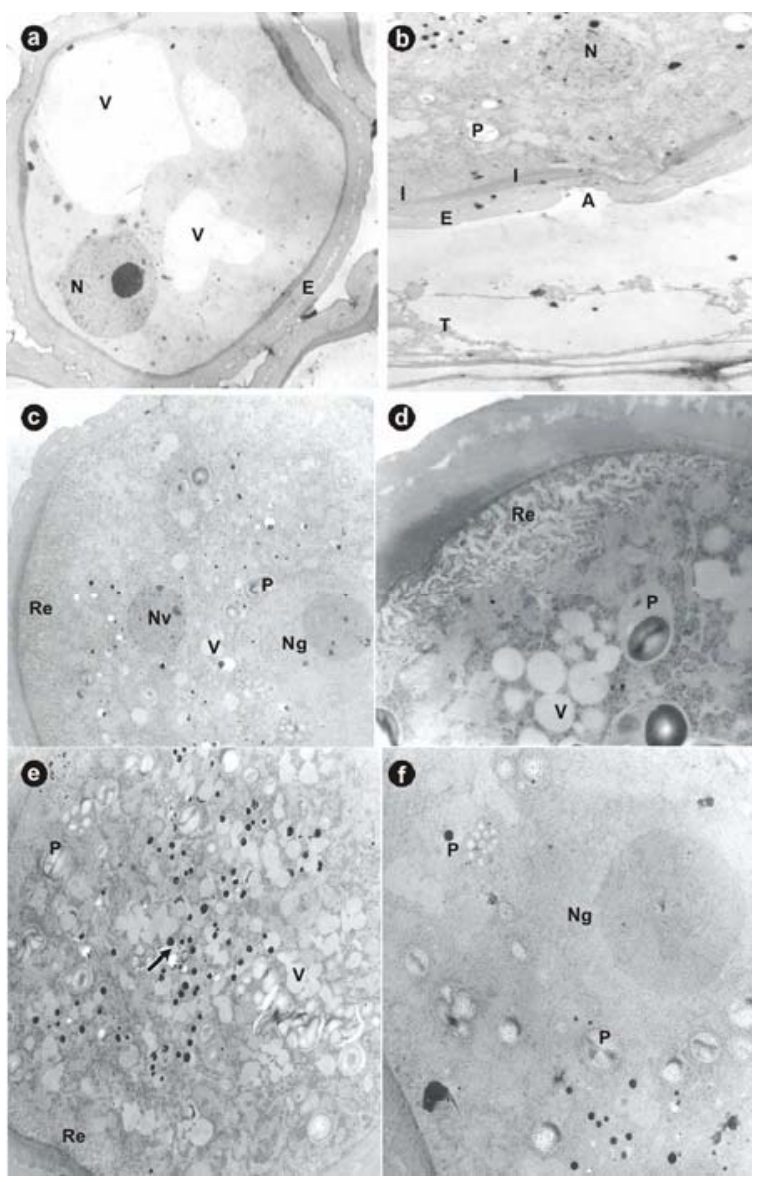

Figure 3 - Ultra structural microphotographs of late phase of pollen grain development. a)Microspore showing the nucleus located close to the cell wall, vacuoles and the exine and intine (x 3000). b) Detail do the microspore showing the aperture pollen grain (x 3000). C)Detail of binuclear mature pollen grain showing the vegetative nucleus and the generative nucleus (x 4400). d) Detail of mature pollen grain showing the reticular endoplasmitic net, vacuoles and plastid (x 12000). e) Detail of mature pollen grain showing lipid droplets close to the endoplasmic reticulum ( $\mathrm{x}$ 4400). f) Generative cell involved by structures plastid like showing the prominent nucleolus (x 12000). V: vacuole; N: nucleus; E: exine; I: intine; A: aperture; $T$ : tapetum; P: plastid; Re: endoplasmatic reticulum; $N v$ : vegetative nucleus; $\mathrm{Ng}$ : generative nucleus

\section{ACKNOWLEDGEMENTS}

We thank Márcia Adriana S.C. Dutra and Arthur Rodrigues, CBB/UENF Photographic Laboratory technicians, for help in developing and amplifying the photographs for this article. This study was supported by FAPERJ and CNPq.

\section{RESUMO}

Esta pesquisa descreve os estádios de formação do gameta masculino (grão de pólen) em mamoeiro. Para isto foram coletados botões florais em diferentes etapas de desenvolvimento e as anteras foram tratadas quimicamente para serem observadas ao microscópio óptico e eletrônico de transmissão. O desenvolvimento do grão de pólen seguiu o padrão normal para Angiospermas. 
Foram descritos os estádios de desenvolvimento do grão de pólen desde meiócitos ou células mães de micrósporos até o grão de pólen binucleado. $\mathrm{Na}$ microesporogênese, as células esporogênicas sofreram meiose dando origem as tétrades, com posterior liberação dos micrósporos da tétrade. A microgametogênese caracterizou-se, principalmente, pela divisão mitótica assimétrica de cada micrósporo originando grãos de pólen binucleados. Estruturas semelhantes a plastídios foram encontradas no citoplasma da célula generativa e agregados próximos ao núcleo da célula generativa. Observou-se degeneração gradativa das células do tapete no decorrer da formação do gameta.

\section{REFERENCES}

Esau, K. (1974), Anatomia das plantas com sementes. Tradução de Berta Lange de Morretes. São Paulo: Ed. Edgard Blucher LTDA.

Damasceno Júnior, P. C. (2004), Estudo reprodutivo em mamoeiro (Carica papaya L.). Doctorate Thesis, Universidade Estadual do Norte Fluminense Darcy Ribeiro, Campos dos oytacazes, RJ, Brasil.

Frankel, R. and Galun, E. (1977), Pollination Mechanisms, Reproduction and Plant Breeding. Springer-Verlag, Berlin Heidelberg New York.

Gabarayeva N. I. (1995), Pollen wall and tapetum development in Anaxagorea brevipes (Annonaceae): sporoderm substructure, cytoskeleton, sporollenin precursor particles, and the endexine problem. Review of Palaeobotany and Palynology, 85:123-152.

Horner, H.T. and Palmer, R.G. (1995), Mechanisms of genic male sterility. Crop Science, 35, 1527-1535.

Humphrey, C. D. and Pittmann, F. E. (1974), A simple methylene blue-azure II basic fuchsin stain for epoxiembedded tissue sections. Stain Technology, 49, 914.

Maheshwari, P. (1950), An introduction to the embryology of angiosperms. New York: McGrawHill.
McCormick, S. (1993), Male gametophyte development. The Plant Cell, 5, 1265-1275.

Noher de Halac I., Cismondi, I. A., Rodríguez-Garcia, M. I. and Famá, G. (2003), Distribution of pectins in the pollen apertures of Oenothera hookeri. Velansster/+ster. Biocell, 27, 11- 18.

Polowick P. L. and Sawhney v. K. (1993), An structural study of pollen development in tomato (Lycopersicon esculentum Mill.) .II. Pollen maturatin. Canadian Journal of Botany, 71, 1048-1055.

Rodríguez-García, M.I., M'rani-Alaoui, M., Fernández, M. (2003), Behavior of storage lipids during development and germination of olive (Olea europaea L.) pollen. Protoplasma, 221, 237- 244.

Ronse Decraene, L.P. and Smets, E.F. (1999), The floral development and anatomy of Carica papaya (Caricaceae). Canadian Journal of Botany, 77, 582598

Souza, M. M. and Pereira, T. N. S. (2000), Development of pollen grain in yellow passion- fruit (Passiflora edulis f.flavicarpa; Passifloraceae). Genetics and Molecular Biology, 23, 469-473.

Spurr A. R. (1969), A low viscosity epoxy resin embedding medium for electron microscopy. Journal of Ultrastructure Research, 26, 31- 43.

Storey, W. B. (1958), Modifications of the sex expression in papaya. Horticultural Advances, 2, 49 $-60$.

Storey, W. B. (1969), Papaya. In: Ferwerda, F. P. and Wit, F. (eds.). Outlines of Perennial Crop Breeding in the Tropics. H. Vienman and Zonen N. V. Wageningen. pp. 389-407.

Venable, J. H. and Coggeshall, R. (1965), A simplified lead citrate stain for use in electron microscopy. Journal of Cell Biology, 25: 407.

Received: March 01, 2006; Revised: February 14, 2007; Accepted: July 16, 2007. 
PÁGINA EM

BRANCO 